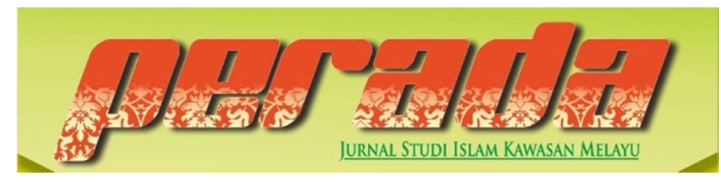

Perada: Jurnal Studi Islam Kawasan Melayu

P-ISSN 2656-7202 E-ISSN 2655-6626

Volume 2 Nomor 2, Juni-Desember 2019

DOI: $10.35961 /$ perada.v2i2.42

\title{
SUMPAH LI'AN DAN MEKANISMENYA DI PENGADILAN AGAMA DALAM PERSPEKTIF FIQH DAN HUKUM POSITIF
}

\author{
ARIS BINTANIA \\ STAIN Sultan Abdurrahman Kepulauan Riau \\ bintania@stainkepri.ac.id
}

\begin{abstract}
Abstrak
Pada tulisan ini penulis melakukan kajian mengenai sumpah Li'an dan mekanismenya di Pengadilan Agama dalam Perspektif Fiqh dan Hukum Islam. Mekanisme Li'an di Lingkungan Peradilan Agama, sebagaimana yang tercantum di dalam Pasal 127 Kompilasi Hukum Islam, mengacu kepada al-Qur'an Surat al-Nur ayat 6 s/d ayat 9. Kemestian terpenuhinya sumpah tidak hanya dari pihak suami sebagai penuduh zina, tetapi juga harus ada pengucapan sumpah dari pihak isteri yang menolak tuduhan tersebut untuk terjadinya cerai dengan jalan Li'an secara normatif adalah untuk memenuhi ketentuan ayat al-Qur'an tersebut.
\end{abstract}

Kata kunci: Sumpah Lian, Peradilan Agama, Hukum Islam.

\section{Abstract}

Ta abstract is not found.

Keywords: Penyucian jiwa; kaedah Islam; ilmu Tasawuf; Tokoh Islam.

\section{PENDAHULUAN}

Legislasi hukum material Islam dalam tatanan kehidupan bernegara ke dalam berbagai produk peraturan dan perundang-undangan adalah sebagai upaya unifikasi hukum Islam untuk menghindari terjadinya ketidakpastian hukum akibat perbedaan putusan terhadap perkara yang sama antara Pengadilan Agama di berbagai wilayah Indonesia.
Akan tetapi berbagai produk peraturan dan perundang-undangan yang dijadikan landasan hukum material Islam bagi Peradilan Agama ternyata dalam penegakannya masih menemui berbagai kendala dan persoalan sehingga dalam penerapannya banyak ditemui perlakuan dan penyikapan yang ambigu (mendua) baik dari institusi hukum maupun dari masyarakat. Bahkan terdapat kecendrungan penegak hukum dan masyarakat hanya menempatkan dan memperlakukan Peradilan Agama berikut 
Produk peraturan dan perundangundangan tersebut hanya sebatas hukum negara yang hanya harus ditaati tidak lebih untuk kepentingan administratif, tanpa ada niatan untuk menganggapnya sebagai peradilan dan hukum Islam dalam artian sesungguhnya yang harus dilaksanakan dan ditegakkan oleh setiap umat Islam.

Ada berbagai alasan yang mempersoalkan produk-produk legislasi hukum material Islam tersebut sebagai belum memenuhi idealitas hukum Islam yang diinginkan karena terdapat banyak modifikasi aturan-aturan di bidang perdata Islam yang berbeda dan berubah dari pemahaman fiqh Islam klasik standar yang selama ini dianut dan diyakini oleh umat Islam di Indonesia. ${ }^{1}$

Di antara berbagai pengaturan yang ambigu dari institusi Pengadilan adalah mengenai Hukum Acara Li'an dan mekanisme penerapannya di lingkungan Peradilan Agama. Dalam pasal 27 Kompilasi Hukum Islam, tatacara penerapan li'an diatur sebagai berikut:

a. suami bersumpah empat kali dengan kata tuduhan zina dan atau pengingkaran anak tersebut, diikuti sumpah kelima dengan kata-kata "laknat Allah atas dirinya apabila tuduhan dan atau pengingkaran tersebut dusta";

b. isteri menolak tuduhan dan atau pengingkaran tersebut dengan sumpah empat kali dengan kata 'tuduhan dan atau pengingkaran tersebut tidak benar', diikuti sumpah kelima dengan kata-kata murka Allah atas dirinya bila "tuduhan dan atau pengingkaran tersebut benar";

c. tatacara pada huruf a dan huruf b tersebut merupakan satu kesatuan yang tak terpisahkan;

1 Amir Syarifuddin, Pembaharuan Pemikiran dalam Hukum Islam, Angkasa Raya, Padang, tt. h. 131-6 d. apabila tatacara huruf a tidak dikuti dengan tatacara huruf b, maka dianggap tidak terjadi li'an.

Memang tatacara li'an yang diatur dalam pasal $27 \mathrm{KHI}$ ini sudah mengacu kepada ketentuan li'an sebagaimana yang dinarasikan al-Qur'an dalam Surat al-Nur ayat: 4,6-9. Akan tetapi ketentuan huruf c yang menganggap tatacara a dan $b$ merupakan satu kesatuan dan diikuti dengan ketentuan huruf $d$ yang menyimpulkan apabila tatacara huruf a tidak diikuti dengan tatacara huruf $b$ dianggap tidak terjadi li'an, perlu dikritisi lebih lanjut.

Ketentuan huruf c dan d, dengan demikian berarti telah mengenyampingkan sumpah li'an yang telah diucapkan oleh suami dan dianggap tidak pernah ada, begitu juga dengan akibat hukum li'annya. Artinya sumpah yang diucapkan oleh suami hanya dianggap sumpah dalam pembuktian biasa dan perceraian terjadi dengan cerai talak sehingga secara hukum tentu si suami di kemudian hari berhak untuk merujuk dan atau memperbaharui akad dengan bekas isterinya, walaupun secara hakiki si suami sudah mengucapkan sumpah li'an, hanya karena isteri tidak mengikuti dengan mengucapkan sumpah penyangkalan.

Tampaknya ketentuan ini tidak sesuai dengan hukum Islam yang direpresentasikan dalam fiqh. Menurut Ibnu Katsir, dalam kitab tafsirnya, apabila sumpah kelima yang disertai laknat Allah atas dirinya jika ia berdusta, telah diucapkan oleh suami menurut mazhab al-Imam al-Syafi'iy dan sekelompok besar ulama lainnya terjadilah li'an dengan sumpah suami itu saja, dan haramlah bekas isterinya itu baginya untuk selamalamanya. Sedangkan sumpah penyangkalan dari si isteri adalah untuk menghindarkan dirinya dari had zina, 
sebagaimana yang disebutkan dalam alQur'an Surat al-Nur ayat 8.

Perbedaan antara ketentuan KHI dengan pendapat figh ini tentu akan berimplikasi kepada hukum perkawinan Islam berikutnya, yaitu sah tidaknya rujuk dan atau perkawinan antara suami yang telah meli'an bekas isterinya yang tidak mengucapkan sumpah penyangkalan.

Inilah di antara persoalan yang akan dikupas dan dibahas dalam tulisan ini

\section{SUMPAH LI'AN DALAM PER- SPEKTIF FIQH}

\section{Pengertian Li'an}

Li'an (اللعان) secara bahasa adalah kata dasar dari kata لاعن maknanya adalah menolak dan menjauhkan diri dari rahmat Allah swt., dan istilah ini sebagai nama dari hasil akibat tindakan suami isteri, karena setiap keduanya melaknat dirinya sendiri dalam sumpah ke-5 jika mereka berdusta. Atau dikarenakan si suami dia lah yang melaknat dirinya sendiri dan juga dari sisi isteri sebagai pengandaian yang lazim, maka dinamakan Li'an karena didasarkan perkataan suami yang memulainya. ${ }^{3}$

Ulama Hanafiah dan Hanabilah mendefinisikan Li'an sebagai: kesaksian-kesaksian yang dikuatkan dengan sumpah-sumpah yang dikaitkan dengan laknat dari sisi suami dan Murka dari sisi isteri, sebagai dasar menegakkan had qazaf (hukum menuduh zina) dari sisi suami dan hukum had zina bagi pihak isteri. Menurut ulama Hanabilah, Li'an untuk

2 Al-Hafiz 'Imaduddin Abi al-Fida' Ismail Ibn Katsir al-Qurasyi al-Dimasyq, Tafsir alQur'an al-'Azim, j-3, cet-1, Maktabah Dar alFiha', 1414H - 1994M. h. 355.; Wahbah alZuhailiy, al-Figh al-Islamiy wa Adillatuhu, cet2, j-7, Dar al-Fikr, Damsyiq, Suriah, 1405H1985M, h. 570 .

3 Wahbah al-Zuhaili, al-Figh al-Islamy wa Adillatuh, Jilid-7, cet-4 Damsyiq-Suriah, Dar alFikr, Th. 1422H/2002M. H. 556. nikah yang fasid (rusak) sah dilakukan tetapi menurut ulama Hanafiyah Li'annya tidak sah.

Ulama Malikiyah memberi pengertian Li'an sebagai: sumpahnya seorang suami muslim mukallaf bahwa ia melihat isterinya berzina atau atas pengingkaran kandungan isterinya, dan si isteri pun bersumpah atas kebohongan suaminya dengan empat kali sumpah dengan redaksi: "Aku bersumpah atas nama Allah telah melihat dia (isterinya) berzina" dan semisalnya, dengan kehadiran Hakim, sama apakah nikah yang sah atau nikah yang fasad. Maka tidak sah jika yang bersumpah bukan suami ${ }^{4}$ atau orang lain, juga orang kafir, anak kecil atau orang gila, dan sumpah itu disaksikan oleh hakim yang menyaksikan sumpah keduanya dan diputuskan dengan terjadinya perceraian atau dihukum had bagi siapa yang menolak bersumpah.

Ulama syafi'iyah memberi pengertian Li'an sebagai, "Kata-kata yang sudah dikenal yang dijadikan hujjah bagi pelaku qazaf (menuduh Zina) terhadap teman seranjang yang ia telanjang dengannya atau untuk mengingkari anak." 5

\section{Penyebab Li'an.}

Penyebab Li'an ada dua hal. Pertama, seorang lelaki mengqazaf isterinya yang jika itu dilakukan oleh orang lain niscaya dilaksanakan had zina. Menurut ulama Malikiyah orang yang menuduh telah melihat isterinya berzina syaratnya ia tidak lagi menyetubuhi isterinya setelah itu, bila ia menuduh tanpa melihatnya maka ia dibad qazaf dan tidak boleh melakukan

\footnotetext{
${ }^{4}$ Wahbah al-Zuhaili, Ibid..

5 Wahbah al-Zuhaili, al-Figh al-Islami..., h.
} 557. 
Li'an, ini pendapat kalangan Malikiyah yang lebih dikenal.

Kedua, mengingkari kehamilan atau mengingkari anak, meskipun lakilaki yang menzinahi tidak jelas siapa atau nikahnya fasid (rusak). Ulama Malikiyah mensyaratkan suami yang mendakwa tidak pernah menyetubuhi isterinya lagi yang menyebabkan adanya anak, dan ia menuduh saat kosongnya rahim dengan satu kali haid, dan ia mengingkari sebelum lahirnya anak, jika ia diam sampai isterinya melahirkan ia dibad dan tidak boleh meLi'an isterinya.

Adapun tuduhan zina bisa terjadi dengan lafaz yang jelas dengan kata Zina, seperti seseorang berkata, "wahai pezina (laki-laki atau perempuan) $)^{6}$, atau dengan kata-kata yang berlaku sebagai kata yang jelas, yaitu dia menafikan (mengingkari) seseorang sebagai anak dari ayahnya yang sudah dikenal, seperti perkataan: engkau bukanlah anak fulan." Atau dengan kata-kata sindiran menurut ulama Syafi'iyah, seperti perkataan, "engkau telah berzina di gunung, di atas atau semisalnya." "Parena perbuatan zina di gunung dan semisalnya itu untuk membuktikannya ia harus mendaki (sulit), jika ia berniat menuduh maka itu termasuk qazaf, dan ini merupakan lafaz yang jelas menurut ulama Hanafiyah.

Atau dengan pendedahan, contoh, "wahai hilal anak si hilal, aku bukan pezina, itu adalah qazaf jika ia meniatkannya menurut ulama Syafi'iyah dan bila dipahami sindirannya itu sebagai tuduhan zina menurut ulama Malikiyah, dan menurut ulama Hanafiyah dan Hanabilah itu bukanlah qazaf." Dan

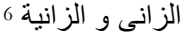

${ }^{7}$ Wahbah al-Zuhaili, al-Fiqh al-Islami...., h.
} 557. ditetapkan qazaf bila ia terbukti dalam had qazaf kadang dengan bukti atau dengan pengakuan.

Adapun untuk mengingkari anak: maka ia menghadirkan seseorang di hadapan hakim dan dia menyebut bahwa anak ini atau kandungan ini bukan dariku, tetapi ulama berbeda pendapat mengenai waktu mengingkari anak dan waktu mengingkari kehamilan.

Menurut Abu Hanifah: jika seorang suami menafi anak yang dilahirkan isterinya di saat melahirkan atau pada waktu ia menerima ucapan selamat yang biasanya tujuh hari, atau pada hari membeli alat-alat perlengkapan melahirkan, maka penafiannya sah dan ia mesti Li'an, karena penafian itu menjadi qazaf (tuduhan zina). Penafian setelah waktu-waktu tersebut tidak sah dan nasab anak ditetapkan padanya, karena itu pengakuan tersirat darinya, yaitu sikap diam dan menerima ucapan selamat, diam itu pertanda ia ridha. ${ }^{8}$

Menurut al-Shahiban, sah menafikan anak dalam masa nifas, karena itu merupakan dampak dari melahirkan. Ulama Malikiyah mensyaratkan dua hal untuk sahnya Li'an dan untuk menafikan anak; pertama suami menyatakan ia tidak pernah menyetubuhi isterinya yang menyebabkan lahirnya anak, atau bahwa setelah menyetubuhi isterinya diselangi haid sekali setelah persetubuhan.; Kedua, ia menafi anak sebelum lahir, bila ia mendiamkan walaupun sehari tanpa ada uzur sampai anak lahir maka ia dihukum had dan tidak bisa meLi'an. Jadi untuk sahnya Li'an disyaratkan segera setelah ia mengetahui kehamilan/kelahiran

${ }^{8}$ Wahbah al-Zuhaili, al-Fiqh al-Islami...., h. 558. 
isterinya, jika terlambat dinyatakan tanpa uzur maka tidak sah. ${ }^{9}$

Ulama Syafi'iyah membolehkan menafi kehamilan menunggu sampai lahir. Karena penafian kehamilan telah pun ditetapkan dalam Sahihain, Bahwa Hilal ibn Umayyah meLi'an kehamilan isterinya, dan adapun menunggu hingga lahir maka agar supaya ia meLi'an dengan yakin. Dan menafi nasab anak dengan segera menurut zahirnya, karena disyari'atkan menolak kemudaratan, seperti menolak aib dan memilih hak syuf ah, tetapi jika ia diam tidak menafi karena adanya uzur maka ia bisa menyampaikannya di malam hari sehingga berakhir sampai subuh, atau jika ia dalam keadaan lapar setelah ia makan, atau jika dalam keadaan telanjang sampai ia berpakaian, maka sah menunda menafi anak karena adanya uzur.

Ulama Hanabilah tidak membolehkan, sebagaimana ulama Hanafiah, menafi kehamilan sebelum melahirkan dan tidaklah menafi hingga ia meLi'annya setelah melahirkan dan menafi anak pada waktu itu, karena keadaan hamil tidaklah meyakinkan, bisa berkemungkinan itu kembung atau masuk angin, dan mereka memberi syarat seperti kalangan Syafi'iyah, bahwa menafi itu mengikut kelahiran, bila seorang perempuan melahirkan anak dan suaminya diam dari pengingkaran padahal ia bisa, maka melekatlah nasab padanya, dan tidak bisa ia menafi lagi setelah itu.

Ringkasnya bahwa para fuqaha punya dua pendapat dalam soal menafi anak di masa kehamilan: pendapat ulama Hanafiah dan Hanabilah tidak membolehkan karena adanya kemungkinan itu bukanlah kehamilan dan pendapat Ulama Malikiyah dan Syafi'iyah membolehkan atas dasar 558-9.

${ }^{9}$ Wahbah al-Zuhaili, al-Fiqh al-Islami...., h. hujjah hadis Hilal ibn Umayyah bahwa ia telah menafi kehamilan, sehingga Nabi pun mengakui penafian itu dan mengaitkannya dengan yang pertama, dan tidak diragukan bahwa itu adalah kehamilan karena sabda Nabi: tunggulah ia jika ia datang dengan begini dan begini, dan karena kehamilan membawa persangkaan dan pertanda yang menunjukkan padanya dan karena sah mengaitkannya dengan kehamilan, maka menafinya itu sama seperti menafi anak setelah ia lahir. Menurut ibn Qudamah: pendapat ini lah yang benar karena sesuai dengan zahir hadis, dan apa yang menyelisihi hadis tidaklah berpengaruh keadaanya.

Untuk mengajukan Li'an menurut jumhur ulama disyaratkan harus segera, setelah suami mengetahui kehamilan atau lahirnya anak dan ulama Hanafiah membolehkan Li'an mengikuti kelahiran atau setelahnya selama tujuh hari. ${ }^{10}$

\section{Dasar Pensyari'atan Li'an}

Pensyari'atan Li'an didasarkan pada al-Qur'an Surat al-Nur ayat 6-9.

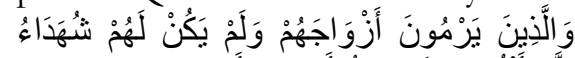

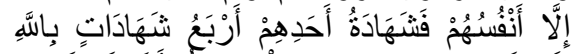

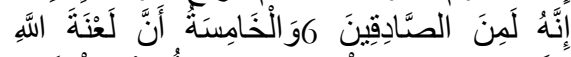

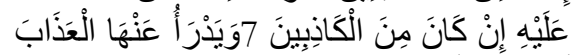

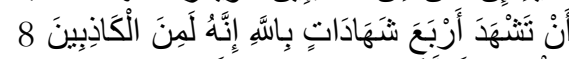

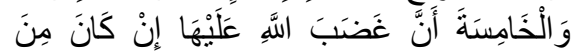

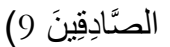

Sebab turunnya ayat adalah riwayat al-Bukhari dll, bahwa Hilal ibn Umayyah mengqazaf isterinya di hadapan Nabi saw. disertai Ibn Sahma'; Nabi berkata: hadirkan bukti atau hukum cambuk pada punggungmu. Ia berkata: wahai Nabi, bagaimana bila kami melihat sendiri seseorang menyetubuhi isterinya, h. 560 .
${ }^{10}$ Wahbah al-Zuhaili, al-Fiqh al-Islami....,

Perada: Jurnal Studi Islam Kawasan Melayu, Vol. 2, No. 2, Desember 2019 
apakah harus menghadirkan bukti (saksi) juga, maka Nabi menetapkan harus ada bukti (saksi), berkata Hilal: Demi yang mengutusMu dengan kebenaran sebagai Nabi, bahwa sungguh aku berkata jujur, semoga Allah menurunkan wahyu yang bisa membebaskan punggungku dari cambukan, maka turunlah ayat ini.

Menurut Jumhur ulama, inilah awal pertama terjadinya Li'an dalam Islam, namun al-Mawardi mensinyalir tentang pernyataan sejumlah ulama yang mengatakan sebelum kisah hilal jauh lebih dulu ada kisah Uwaimir, dan meriwayatkan seluruh ulama hadis kecuali al-Turmuzi, bahwa Nabi bersabda kepada Uwaimir al-'ajlani, bahwa sungguh ayat ini turun mengenai dirimu dan mengenai sahabatmu, maka ia pergi dan datang dengannya maka keduanya saling meLi'an di hadapan Nabi, dan ini pendapat Nawawi dalam syarah Muslim bahwa sebab turunnya ayat Li'an adalah kisah Uwaimir al-'Ajlani. ${ }^{11}$

Berdasarkan riwayat ini maka dalam mengqazaf berbeda hukumnya antara pasangan suami isteri dan yang bukan, jika yang mengqazaf orang lain atau lelaki yang bukan suami dari perempuan yang dituduhnya, kemudian ternyata wanita itu suci, sementara penuduh tidak dapat menghadirkan empat orang saksi lelaki yang bersaksi akan kebenaran dugaan itu, maka ia dihukum had qazaf sebanyak 80 kali cambuk, sebagai ganjaran baginya dan bagi pelaku maksiat yang semisal itu. Adapun bila seorang suami menduga isterinya sendiri berzina atau ia mengingkari nasab anaknya, dan ia tak mampu mendatangkan empat orang saksi maka ia tidak dihukum had qazaf, h. 560 .

11 Wahbah al-Zuhaili, al-Fiqh al-Islami...., hanya saja di syari'atkan dalam soal ini dengan Li'an. ${ }^{12}$

Dan ini sudah disepakati mengenai riwayat dalam menjelaskan sebab turunnya ayat Li'an dengan tiga kejadian: Pertama, bahwa ayat Li'an turun setelah ayat Qazaf terhadap Perempuan baik-baik dengan mengakhirkannya dan dia pemilahnya. Kedua, bahwa mereka sebelum turunnya ayat Li'an memahami ayat 5 surat al-Nur (tentang menuduh perempuan baik-baik berzina) sebagai ayat qazaf karna hukum orang yang menuduh seorang wanita asing berzina dan hukum orang yang menuduh isterinya sama. Ketiga, bahwa ayat Li'an turun sebagai keringanan bagi seorang suami dan sebagai penjelas untuk mengeluarkannya dari apa yang menimpanya secara paksa.

Dasar disyari'atkannya Li'an adalah atas kebohongan yang jelas sebagaimana bolehnya meminta dengan Li'an atas orang yang zalim karena firman Allah swt. ${ }^{13}$

$$
\text { الا لعنة الله على الظالمين }
$$

4. Rukun dan Syarat-syarat Li'an dan Syarat Dua orang Pelaku Li'an

Menurut Ulama Hanafiah rukun Li'an satu yaitu Lafaz, yaitu pernyataan yang dikuatkan dengan sumpah, dan Li'an itu dari kedua suami isteri. Menurut Jumhur ulama rukun Li'an itu ada empat; Mula'in (peLi'an), Mula'anah (saling sumpah Li'an), sebab dan lafaznya.

Syarat-syarat Li'an ada dua macam: yaitu syarat wajib (mesti)nya Li'an dan syarat syahnya dibolehkan Li'an. Pertama, Syarat wajib (mesti)nya Li'an: menurut ulama Hanafiah ada tiga:

\footnotetext{
12 Wahbah al-Zuhaili, al-Fiqh al-Islami...., h. 561.

13 Wahbah al-Zuhaili, al-Figh al-Islami...., h. 562 .
} 
a. Adanya perkawinan dengan perempuan itu meskipun belum digauli atau masih dalam masa 'iddah talaq raj'iy, karena firman والذين يرمون ازواجهم . Allah swt. Maka tidak ada sumpah Li'an antara orang yang bukan suami isteri. Jika seseorang mengqazaf seorang wanita kemudian ia menikahinya maka ia pun harus menjalani had qazaf dan tidak boleh ia meLi'an, karena kedudukan yang berlaku ia masih wanita asing (bukan isteri). Kemudian juga tidak ada Li'an dengan menuduh isteri yang sudah mati, karena mayat bukan lagi isteri, dan karena Li'an tidak akan bisa datang darinya. Dan juga tidak bisa Li'an atas seorang isteri yang sudah ditalak ba'in, maka dihad suami asalnya itu sebagai orang asing. Dan ini syarat yang disepakati kecuali isteri yang ditalak bain karena menurut jumhur boleh Li'an padanya.

Menurut jumhur sah Li'an dari yang bukan suami dalam dua keadaan: Talak Ba'in untuk mengingkari anak dan yang disetubuhi dengan nikah fasid atau syubhat, tetapi jika suami itu murtad setelah menyetubuhinya kemudian ia mengqazaf dan kemudian ia Islam pada masa iddah maka ia meLi'an, jika ia meLi'an kemudian ia Islam di masa iddah maka sah lah Li'annya, karena jelas terjadinya dalam masa pernikahan.

b. Kedudukan Nikahnya adalah nikah yang sah dan bukan nikah fasid.

Tidak ada Li'an dalam mengqazaf wanita yang dinikahi secara fasid, karena dia orang asing, ini berbeda dengan pendapat jumhur yang membolehkan meLi'an isteri yang dinikahi secara fasid karena nasab anak ada padanya, seperti menikah tanpa wali atau tanpa saksi, kemudian ia mengqazafnya, tetapi boleh Li'an dalam keadaan ini tergantung bila didapati dari keduanya anak yang ingin diingkarinya, tetapi jika tidak ada anak yang akan diingkari maka suaminya dihad dan tidak boleh Li'an. $^{14}$

c. Keadaan suami mampu menyatakan kesaksiannya. Kedua suami isteri adalah orang merdeka, berakal, baligh, muslim, bisa bicara, tidak pernah dihad qazaf. Tidak ada Li'an bagi dua orang yang kafir tidak juga dari salah satunya baik seorang hamba, anak kecil atau orang gila, atau orang yang pernah dibad qazaf atau orang kafir, atau terkenal banyak syubhat, dan boleh di antara dua orang yang buta dan fasik, karena keduanya mampu menyatakan kesaksian akan tetapi tidak diterima kesaksian karena fasiknya dan karena tidak adanya kemampuan memilah pada orang buta. Singkatnya ulama Hanafiah mensyaratkan kemampuan menyatakan kesaksian pada suami karena kata-kata Li'an adalah pernyataan kesaksian dan disyaratkan juga keadaannya sebagai suami isteri dari orang yang dihad pelaku qarafnya, karena Li'an mengganti had qazaf pada penuduh orang asing (bukan suami). Tetapi jumhur tidak mensyaratkan kedua hal ini.

Tetapi ulama Malikiyah mensyaratkan beragama Islam pada suami saja tidak pada isteri,

14 Wahbah al-Zuhaili, al-Figh al-Islami...., h. 563.

Perada: Jurnal Studi Islam Kawasan Melayu, Vol. 2, No. 2, Desember 2019 
karena wanita zimmi dapat melakukan Li'an untuk menghilangkan aibnya, dan menurut mereka disyaratkan orang yang saling meLi'an itu keadaanya baligh dan berakal baik orang merdeka maupun hamba, keduanya adil atau pun fasiq, dan terjadinya Li'an disepakati dalam keadaan suci, dan dalam masa iddah talak raj'iy dan talak ba'in. Ini berbeda dengan ulama Hanafiyah dan setelah iddah dalam mengingkari kehamilan sampai puncak masa kehamilan, dan terjadinya lian dari suami isteri dalam nikah sah dan nikah fasid.

Ulama Syafi'iah dan Hanabilah tidak mensyaratkan Islam pada dua peLi'an, mereka berpendapat Li'an sah bagi setiap suami yang talaknya sah, bahwa kedua suami isteri itu haruslah sudah dewasa yaitu baligh dan berakal apakah keduanya muslim maupun kafir apakah keduanya adil atau pun fasiq atau pun keduanya pernah dihad qazaf atau pun salah satunya. Dan Li'an juga sah dari orang merdeka, hamba sahaya, orang cerdas, orang bodoh, orang hilang akal karena mabuk, orang hebat atau pun orang bodoh yang mengerti isyarat menurut Syafi'iyah, dan dari orang yang mentalak raj'iy, dan juga sah dari suami yang mentalak ba'in untuk mengingkari anak, begitu juga pendapat ulama Hanabilah, jika tidak ada anak. Menurut mereka sah Li'an wanita yang digauli dengan nikah fasid atau syubhat karena dugaannya itu isterinya yang ia qazaf dan ia Li'an untuk mengingkari nasab sebagaimana dijelaskan. ${ }^{15}$

Disepakati Li'an dari seorang anak atau orang gila tidak sah, tidak ada Li'an bila satu dari suami isteri bukan mukallaf, karena Li'an adalah perkataan yang mengakibatkan perceraian, sama juga dalam hal talak dan sumpah, tidak ada Li'an juga antara orang yang bukan suami isteri, bila seseorang mengqazaf wanita bukan isterinya yang suci maka ia dihad qazaf dan tidak boleh Li'an.

Dalam Li'an, tidak berbeda apakah keadaan isterinya sudah digauli atau pun belum, karena والذين يرمون ازواجهم firman Allah jika isterinya belum digauli maka ia berhak separuh dari maharnya, karena itu termasuk cerai dari suami. Orang bisu dapat meLi'an menurut ulama Hanabilah tetapi orang bodoh tidak bisa karena ia tidak mengerti apa yang ia inginkan, dan mereka sepakat bahwa tidak sah Li'an dari orang bisu dan bodoh yang tidak tahu isyarat dan tulisan.

Kesimpulannya, ulama Hanafiah mensyaratkan dua orang peLi'an harus: Islam, bisa bicara, merdeka, dan adil. Dan kedudukan Li'an dalam perkawinan secara hukum sama seperti talak raj'iy dan bukan talak ba'in dan berbeda syarat-syaratnya menurut jumhur ulama bahwa ulama Malikiyah mensyaratkan Islam pada suami saja mereka sepakat dengan syarat mukallaf, baligh dan berakal dan sah Li'an dari orang bisu menurut jumhur kecuali ulama Hanafiah. Ulama Hanabilah menyebutkan tiga

15 Wahbah al-Zuhaili, al-Fiqh al-Islami...., h. 564 . 
syarat Li'an yakni: pertama, Terjadi pada dua orang suami isteri, walaupun belum digauli; kedua, didahului tuduhan suami bahwa isterinya telah berzina, seperti: engkau telah berzina; atau panggilan wahai pezina; atau aku melihatmu berzina, Ini disepakati sebagai sebab Li'an. Adalah hak suami menuduh isterinya berzina jika ia tahu, atau menduga dengan dugaan yang kuat, seperti menduga isterinya telah berzina dengan seseorang karena melihat keduanya berkhalwat. Ketiga, Jika ia berdusta padanya dan terus menyangkal sampai diselesaikan dengan Li'an. Tetapi jika ia membenarkan walaupun sekali, (h. 565) atau isteri minta keringanan dari had dan ta'zir atau ia diam atau terbukti zinanya dengan empat saksi lain maka tidak ada Li'an dan nasab tidak padanya, dan karena ini lah tidak sah Li'an menurut Hanabilah dari orang bisu. ${ }^{16}$

\section{Bahasa Li'an:}

Menurut jumhur ulama selain Hanabilah, Li'an sah dengan bahasa Arab dan bahasa Lain, karena Li'an itu adalah sumpah dan kesaksian yang itu sama dalam bahasa mana saja, Li'an itu maksudnya persaksian, sumpah dan marah. Tetapi menurut ulama Hanabilah jika suami isteri itu bisa berbahasa arab, maka tidak boleh mengucapkan Li'an dalam bahasa lain karena Li'an di dalam al-Qur'an dalam bahasa Arab.

\section{SYARAT SAH BERLAKUNYA LI'AN PADA ZATNYA.}

16 Wahbah al-Zuhaili, al-Fiqh al-Islami...., h. $565-6$
Ulama Hanabilah menyebut enam syarat berlakunya Li'an, sebagian disepakati sebagian diperselisihkan:

1. Harus dihadiri Hakim atau penggantinya, ini disepakati karena Hadis Nabi yang memerintahkan Hilal ibn Umayyah untuk mendakwa isterinya di hadapannya dan keduanya saling meLi'an. Karena mendakwa dengan sumpah, tidak sah Li'an kecuali atas perintah hakim, sama seperti sumpah dalam seluruh sengketa. Dan ini menghendaki adanya pengajuan perkara dari salah seorang suami isteri pada hakim. Jika kedua suami isteri melakukan pengucapan Li'an tanpa dihadiri hakim maka itu tidak sah. Karena Li'an dibina atas kekuatan dan ketegasan maka tidak boleh dilakukan tanpa kehadiran hakim, sama seperti hukum had.

2. Dilakukan setelah diminta oleh Hakim, keduanya mengucapkan setelah diminta, jika ia mendahului mengucapkan Li'an sebelum diminta maka itu tidak sah, sama seperti ia bersumpah sebelum diperintah hakim, ini juga disepakati.

3. Sempurnanya lafaz Li'an yang lima, jika lafaznya kurang tidak sah, dan ini disepakati.

4. Bahwa kedua suami isteri sama-sama mengucapkan redaksi Li'an sebagaimana dinarasi oleh al-Qur'an. Fuqaha berbeda pendapat dalam soal menggantinya dengan lafaz semakna, انى لمن الصادقين seperti menukar kata kata لقد زنت الكن atau berkata sebagai ganti لقد كذب dengan kata انه لمن الكاذبين. Menurut ulama Hanabilah pada dasarnya ini boleh karena maknanya sama. Tetapi jika ditukar dengan kata اشتهد dengan lafaz-lafaz sumpah yang lain seperti kata احلف اقسم او اولي maka ia tidak sama dengannya menurut ulama Syafi'iyah dan Hanabilah karena yang jadi patokan adalah lafaz Syahadah sehingga lafaz lain tidaklah 
sama dengannya seperti kesaksian dalam hak-hak. Karena Li'an itu menghendaki ketegasan dan kata Kesaksian itu lebih mencerminkan ketegasan sehingga tidak boleh ditinggalkan, dan karena ini juga tidak boleh bersumpah atas nama Allah tanpa kalimat yang berlaku sebagai kata aku bersaksi اشته dan pada dasarnya ini juga pendapat ulama Hanafiah dan Malikiyah juga.

5. Tertibnya susunan lafaz Li'an, yaitu Suami lah yang memulai lafal sumpah kepada isterinya, kemudian diikuti sumpah isteri, jika lebih dulu lafaz laknat dari lafal sumpah yang empat atau lebih dulu sumpah Li'an isteri atas sumpah Li'an suami, ini tidak dianggap, dan ini disepakati. Karena Li'an menurut ulama Hanafiyah adalah kesaksian, perempuan dengan kesaksiannya bertujuan menyangkal kesaksian suami, sehingga tidak sah sebelum diucapkan sumpah kesaksian suami lebih dulu.

6. Ada isyarat yang menunjuk kepada salah satu pasangan terhadap yang lain bila keduanya hadir, menyebut namanya dan menyandarkan padanya jika ia tidak hadir, ini disepakati oleh fuqaha. Ulama Syafi'iyah dan Hanabilah tidak mensyaratkan hadirnya suami isteri secara bersamaan, tetapi jika salah satunya tidak ada maka boleh, seperti suami meLi'an di masjid sementara isterinya ada di pintu karena ketidakmungkinannya masuk ke masjid. Ulama Malikiyah mensyaratkan adanya orang yang hadir dalam majlis Li'an paling sedikit empat orang yang adil, menurut ulama Syafi'iyah dan Hanabilah, disunnahkan dalam Li'an dihadiri oleh sekumpulan orang Islam, karena Ibn Abbas dan Ibn Umar dan Sahl ibn Sa'ad ikut menghadiri peristiwa mereka, maka itu menunjukkan bahwa hadir banyak orang, karena anak-anak juga hadir dalam majlis mengikut orang laki-laki, karena Li'an itu dibina atas ketegasan, bersangatan dan segera sehingga melakukannya dalam kumpulan orang lebih patut dan disunnahkan tidak kurang dari empat orang karena bukti saksi dalam zina yang disyari'atkan bagi yang menuduh zina adalah empat orang.

Untuk sahnya Li'an ulama Malikiyah mensyaratkan: suami mutlak tidak boleh lagi menggauli isterinya setelah ia melihatnya berzina atau setelah ia tahu kehamilan atau kelahiran isterinya akibat perbuatan orang lain, bila ia menyetubuhinya maka ia dicegah/dilarang mengucapkan Li'an padanya dan tidak dimungkinkan darinya.

Dan disyaratkan juga menyegerakan Li'an setelah ia tahu kehamilan atau lahirnya anak, jika Li'annya terlambat meskipun sehari tanpa ada uzur, maka terlaranglah Li'an suami pada isterinya dan tidak juga dimungkinkan darinya juga.

Juga disyaratkan lafaz "aku bersaksi” اشثهر empat kali dari suami dan dari isteri dan Li'an (laknat) pada yang kelima bagi suami dan murka غضب pada sumpah kelima dari isteri, sebagaimana yang disebut dalam nash dalam tentang sumpah Li'an.

Suami meLi'an jika ia melihat dengan yakin isterinya berzina, dan penglihatan dari mata...., dan adapun orang buta maka berpegangan pada rasa. atau kabar yang menyebabkannya menuntut walaupun berasal dari perempuan. ${ }^{17}$

\section{SYARAT-SYARAT MENAFI ANAK}

Ulama Hanafiah mensyaratkan 6 hal untuk mengingkari anak dan meniadakan hubungan nasab, yakni:

17 Wahbah al-Zuhaili, al-Fiqh al-Islami...., h. 566-7. 
1. Sebelumnya Hakim telah memutus perceraian antara suami isteri, karena perkawinan sebelum terjadi perceraian masih berlaku maka tidak mesti menafi.

2. Penafian anak setelah kelahiran harus segera dan seketika, atau sehari dua setelah itu paling lama tujuh hari yang menurut kebiasaan orang mengucapkan selamat atas kelahiran, bila ia menafi lewat dari itu maka tidak lagi berlaku. Menurut al-Sahibani; ketentuan waktu menafi anak disesuaikan dengan banyaknya masa nifas yaitu 40 hari. Sementara jumhur mengendaki penafian anak harus segera, jika menunda tanpa uzur maka pengingkaran tidak sah.

3. Tidak didahului oleh pengakuan anak meskipun hanya pertanda atau sikap tanggungjawab, seperti penerimaan ucapan selamat tanpa ada penolakan.

4. Anak tetap hidup sewaktu putusan perceraian, yakni anak dalam keadaan hidup pada waktu perceraian.

5. Bahwa setelah perceraian perempuan tersebut tidak lagi melahirkan anak yang lain, jika ia kembali melahirkan anak sehingga suami menafinya, maka hakim menerapkan Li'an bagi keduanya, keduanya diputus cerai, dan anak dinasabkan ke ibunya. Atau ia telah menceraikan isterinya yang kemudian kembali melahirkan anak lain maka niscayalah kedua anak itu semuanya, karena tetapnya nasab anak kedua yang tidak tercakup padanya Li'an, karena hukum Li'an telah batal dengan perpisahan (perceraian), maka tetaplah nasab anak yang kedua, kemudian ditetapkan juga nasab anak yang pertama.

6. Ia tidak pernah dihukum penetapan nasab anak secara syar'iy, seperti seorang wanita melahirkan anak yang diserahkan ke penyusuan yang kemudian penyusu itu meninggal maka diputuskan dasarnya kepada bapaknya, kemudian ia mengingkari nasabnya, maka hakim menerapkan Li'an bagi keduanya, maka tidaklah terputus nasab anak, karena putusan hakim itu dengan diat (tebusan) kepada orang berakal sebagai ketetapan dengan keadaan anak darinya. Dan tidak lah terputus nasab setelahnya.

Syarat penafian kehamilan menurut ulama Malikiyah:

1. Suami menyatakan bahwa ia belum pernah menyetubuhi isterinya setelah akad nikah atau dengan sengaja berhubungan dengannya atau ia telah menyetubuhinya tetapi ia telah kosong dengan haid sekali. Jika ia belum menyetubuhinya setelah akad atau ia telah menggaulinya kemudian ia datang membawa anak setelah hubungan dalam suatu masa yang tidak terkait dengan anak padanya dengan perkawinan, bisajadi karena singkatnya waktu seperti ia melahirkan anak dengan sempurna setelah sebulan atau dua bulan atau lima bulan setelah percampuran atau persetubuhan. Karena masa hamil paling singkat adalah enam bulan setelah persetubuhan dan bisa jadi karena lamanya masa hamil yaitu lima tahun karena masa hamil terlama adalah empat tahun setelah bersetubuh, maka jika dalam dua keadaan ini, itu diakui. Maka diketahuilah secara pasti bahwa anak itu bukan berasal dari suaminya sehingga untuk menafinya dilakukan Li'an.

2. Menafi anak sebelum ia dilahirkan, jika ia diam walau sehari tanpa uzur sampai ia melahirkan, maka suami dihukum had (qazaf) dan tidak bisa Li'an. Adapun ulama Syafi'iyah mereka membolehkan menafi anak pada masa kehamilan atau langsung setelah kelahiran, jika menunda tanpa uzur atau sebelum menerima ucapan selamat, maka gugur haknya menafi, 
karena penundaan mengandung makna pengakuannya. Jika ia mengaku tidak mengetahui kelahiran, jika ia berada di tempat/daerah yang dekat maka perkataannya tidak diterima, karena pengakuannya bertentangan dengan kenyataan yang ada. Tetapi jika memang ia berada di tempat yang memungkinkan ia tidak mengetahui kelahiran seperti negeri yang besar (perkotaan) maka satu pendapat pengakuannya harus bersama dengan sumpahnya karena apa yang dia akui itu nyata. Mereka berpendapat tidak sah mengingkari salah satu dari dua anak kembar, jika datang seorang wanita dengan dua anak kembar, yang satu diingkari dan yang lain diakui, atau ia meninggalkan penafian tanpa uzur, maka kedua anak itu dihubungkan dengannya, karena kandungannya satu. Karena Allah swt. tidak pernah berlaku menurut sunnatullah dalam satu rahim berkumpul dua janin yang berasal dari air mani dua lelaki.

Dan mestilah si suami menafi anak yang dibawa oleh isterinya dan ia tahu bahwa itu bukan berasal darinya. Karena ia menggaulinya atau melahirkannya tidak sampai enam bulan dari persetubuhan. Atau di bawah empat tahun tetapi jika melahirkannya di antara enam bulan dari persetubuhan dan empat tahun itu dan ia tidak lagi mendapat haid setelah itu maka haram menafi anak dengan Li'an untuk memelihara perkawinan. Jika ia melahirkan enam bulan setelah bebas haid maka pastilah enam bulan ke atas itu dari zina, maka halal lah menafi anak dengan Li'an menurut pendapat yang lebih benar, tetapi pada keadaan yang pertama untuk tidak menafinya karena kehamilan telah melihat darah (haid).

Menurut ulama Hanabilah syarat menafi anak antara lain:
1. Tidak didahului pengakuan atau dengan kembarnya atau dengan indikasi seperti itu, sepertii jika ia menafi salah satu anak kembar dan mendiamkan (tidak menafi) anak yang lain. Pendapat ini sama dengan ulama Syafi'iyah.

2. Penafian anak dilakukan setelah melahirkan, jika ia menyukai sehingga ia diam atau mengakui imbauan atau melambatkan penafian padahal mungkin dilakukannya, karena mengharap kematiannya tanpa ada uzur semisal lapar, haus atau tertidur, maka gugurlah haknya untuk menafi. Jika ia berkata saya tidak mengetahui adanya anak ini atau melambatkan menafi karena ada uzur seperti tersandra atau sakit atau hilang (sesat) atau sedang menjaga harta maka haknya tidak gugur, pendapat ini juga sama dengan ulama Syafi'iyah.

3. Bahwa dalam sumpah Li'an kedua suami isteri menyebut tentang pengingkaran anak, karena keduanya sama-sama bersumpah sehingga disyaratkan menyebut soal itu. Menurut ulama Syafi'iyah cukup menyebut soal anak pihak laki-laki saja dan tidak perlu pihak wanita karena ia tidak menafinya. Menyebut tentang anak dalam ucapan lebih kuat menurut ulama Hanabilah dengan perkataan: "Anak ini bukan lah anakku" dan yang wanita berkata "Anak ini adalah anak dia”. Menurut Qadi Abu Ya'la dan ulama Syafi'iyah; Disyaratkan suami berkata: "Anak ini adalah anak hasil zina, dan dia bukan dariku", karena ia ingin mengatakan "dia bukan berasal dariku" penciptaan dan kejadiannya maka ia harus menyebutnya untuk menegaskannya.

4. Li'an didapat dari kedua suami isteri, dan ini pendapat mayoritas ulama, menurut Imam Syafi'iy, anak dinafi dengan Li'annya suami saja, karena menafi anak itu dengan sumpah suami 
bukan sumpah isteri yang menyatakan dusta suami, sumpah isteri juga tidak bermakna menafi nasab anak bahkan ia meneguhkannya dan menyatakan suami dusta, karena Li'annya wanita untuk menghindar dari hukuman had zina. Tetapi jumhur menolak pendapat ini karena Nabi saw. menafi anak dari pihak laki-laki terjadi setelah keduanya berLi'an.

5. Sempurnanya lafaz Li'an dari kedua suami isteri sekalian.

6. Dimulai dengan Li'an suami dahulu baru diikuti Li'an pihak wanita, menurut ulama Malikiyah dan Hanafiyah jika dilakukan sebaliknya itu menyalahi sunnah, dan perpisahan terjadi dan anak dinafi darinya.

\section{TATACARA LI'AN DAN KEHA- DIRAN HAKIM}

\section{a. Tatacara Li'an, sifat dan lafaz- lafaznya.}

Berdasarkan Qur'an Surat alNur, Ayat: 6-9, maka apabila seorang suami mengqazaf isterinya atau menafi nasab anak yang dilahirkannya sedang ia tidak memiliki bukti dan isterinya tidak mengakui Dan ia menuntut penegaka had qazaf atasny, maka hakim memerintahkannya melaksanakan Li'an yang dimulai oleh suami dengan mengatakan di hadapan hakim sebanyak empat kali "شهر بالهة " aku bersaksi atas nama Allah bahwa aku orang yang benar/jujur atas apa yang aku tuduhkan padanya dari Zina atau menafi anak, bahwa maksud telah dibatasi dengan isyarat pada isterinya jika ia hadir atau (h. 572) dengan menyebut nama dengan perkataan: pada yang aku tuduh si fulanah isteriku dari zina, kemudian ia berkata kali kelima, laknat Allah atas dirinya jika ia orang pendusta pada apa yang ia tuduhkan pada isterinya dari zina atau menafi anak dan suami menunjuk pada isterinya pada semua yang ia sebutkan.

Kemudian si isteri berkata empat kali juga, "sungguha ia (suaminya) adalah pendusta pada apa yang ia tuduhkan padaku dari zina atau penafian anak, dan ia mengatakan kali kelima, bahwa murka Allah atas dirinya jika suaminya benar pada tuduhannya bahwa aku berzina atau penafian anak, dan sesungguhnya dikhususkan kata " murka karena itu paling kuat dalam Li'an bagi pihak perempuan, karena perempuan sangat mengesalkan dengan zina, maka mereka menggunakan Li'an dalam ucapannya dengan banyak, sebagaimana riwayat hadis, maka ia diuji dengan Li'an untuk memurnikan dan tidak mendahuluinya, dan juga karena kejahatannya yaitu zina jauh lebih besar dari kejahatan suami yaitu qazaf, dan wajib si suami yang memulai duluan dalam Li'an, karena ia pendakwa, dan dalam dakwaan pendakwa yang memulai duluan.

Berdasarkan sunnah yang menguatkan dalil al-Qur'an ada banyak hadis, di antaranya hadis Ibn Umar: ia berkata: Wahai Rasulallah bagaimana pendapatmu jika salah satu dari kami mendapatkan isteri kami berbuat keji, apa yang ia perbuat, jika ia bicara maka ia bicara perkara besar, jiak ia diam maka ia juga mendiamkan hal yang besar: maka Nabi diam dan tidak menjawab, dan setelah itu, ia mendatanginya dan berkata sesungguhnya yang aku tanyakan padamu itu terjadi pada diriku, maka Allah turunkan ayat-ayat Surat al-Nur ini. Maka dibacakanlah ayat itu padanya dan rasul mengingatkan dan menyebut bahwa azab dunia jauh lebih baik dari azab akhirat, maka ia 
menjawab tidak, dan demi Zat yang mengutusmu dengan Haq, aku tidaklah berdusta tentangnya kemudian Rasul memanggil isterinya dan menasehatinya dan mengabarkan bahwa azab dunia jauh lebih baik ketimbang azab akhirat, maka isterinyapun menjawab tidak, dan demi zat yang mengutusmu dengan haq, sungguh ia pendusta.

Maka suami memulai duluan, ia bersaksi empat kali kesaksian atas nama Allah bahwa ia termasuk orang yang benar dan kali kelima laknat Allah atas dirinya jika ia pendusta kemudian diikuti oleh si isteri bersaksi sebanyak empat kali atas nama Allah bahwa suaminya adalah pendusta dan sumpah kelima murka Allah atas dirinya jika suaminya benar, kemudian Nabi menceraikan keduanya. (Hadits Muttafaq Alaih antara Ahmad, Bukhari dan Muslim dari Sa'id ibn Jabir dari Ibn Umar).

Menurut Abu Hanifah boleh juga perempuan yang memulai duluan dengan Li'an, tetapi menurut al-Kasani dalam kitab al-Bada'i', ia sebaiknya mengulangi, karena Li'an kesaksian perempuan dan kesaksian perempuan menyanggah kesaksian suaminya, sehingga tidak sah melainkan setelah wujudnya kesaksian suami. ${ }^{18}$

\section{b. Anjuran dalam Li'an dan keharusan adanya Hakim}

Disunnahkan bagi Hakim untuk melakukan hal-hal sebagai berikut:

a. Menasehati kedua suami isteri sebelum melakukan Li'an, dan mewanti-wanti keduanya akan azab Allah di akhirat, sebagaimana yang dilakukan Nabi terhadap Ibn Umar dan isterinya, dan Sabda Nabi kepada Hilal: Takutlah pada Allah karena azab dunia jauh lebih baik

18 Wahbah al-Zuhaili, al-Fiqh al-Islami...., dari azab akhirat dan membacakan kepada keduanya ayat:

ان الذين يشترون بعهد الله ثمنا قليلا الاية

Dan mengatakan pada keduanya bahwa Nabi telah bersabda kepada dua suami isteri yang melakukan Li'an: bahwa Hisab Allah atas kalian berdua, ia maha mengetahui bahwa satu dari kalian adalah pendusta, maka adakah dari kalian berdua yang mau bertaubat?

b. Hakim tidak boleh menghukum Li'an sampai jelas baginya status pernikahan keduanya.

c. Bahwa keduanya mengucapkan Li'an dengan berdiri supaya dapat dilihat orang banyak, dan mengumumkan perkara keduanya, suami berdiri ketika mengucapkan Li'an dan isterinya duduk, kemudian isteri berdiri ketika mengucapkann sumpah Li'annya dan suaminya duduk, dan keduanya mengucapkan lafaz-lafaz Li'an yang berjumlah empat kali kesaksian.

d. Di hadiri oleh sekelompk orang Islam, paling sedikit empat orang yang adil, dan ulama Malikiyah mewajibkan ini.

e. Mengutamakan pelaksanaan Li'an dari segi tempat dan waktu. Menurut ulama Malikiyah, Syafi'iyah dan Hanabilah dilakukan setelah shalat sebagai pelajaran dan preventif, atau setelah shalat ashar, karena ia shalat di pertengahan waktu, atau setelah shalat ashar hari jum'at, karena waktu mustajab sebagaiana diriwayatkan Abu Daud dan al-Nasa'iy, karena sumpah palsu diwaktu setelah Ashar hukumannya paling berat karena sabda Nabi saw; ada tiga jenis orang yang Allah tidak akan berbicara padanya di hari kiamat dan tidak juga mensucikan mereka, bagi mereka azab yang pedih, termasuk di antara mereka lelaki h. $572-3$. 
yang bersumpah dusta setelah shalat Ashar, yang memutus dengannya harta seorang lelaki muslim.

Dan hendaklah Li'an orang muslim dilakukan di masjid, karena tempat paling mulia, dan ulama Malikiyah mewajibkan di masjid karena di dalam masjid ada penguatan pengaruh supaya tidak sumpah palsu. Tempat paling mulia adalah di Makkah, di antara hajar aswad dan maqam Ibrahim yang dinamakan alHathim dan di Madinah pada mimbar yang menghampiri makam Nabi, Karena adanya hadits Nabi SAW: Siapa yang bersumpah di atas mimbarku ini sumpah pendosa disediakan kursinya dari api neraka. Dan sabda belai: Jangan bersumpah di mimbar ini baik seorang hamba atau pun merdeka sumpah pendosa meskipun hanya di atas sauk basah tidak ada ganjaran kecuali neraka. Dan Li'an di Baitil Maqdis dan mengadakan Li'an di selain masjid yang tiga itu, mesti dilakukan di atas mimbar masjid jami', karena itu tempat yang paling agung, dan perempuan yang haid atau nifas atau diragukan kemuslimahannya mengucapkan Li'an di pintu masjid jami'. Orang Kafir zimmi atau ahl alkitab mengucapkan Li'an di Bi'ah tempat ibadah untuk orang Nasrani dan di Kanisah tempat ibadah orang Yahudi, karena tempat ibadah mereka sama seperti Masjid di kita dan orang Majusi meLi'an di rumah api karena mereka mengagungkan tempat itu, tujuannya untuk menghindari kebohongan. Dan hadirnya hakim untuk menjaga aqidah mereka dari syubhat kitab yang mereka akui, dan tidak boleh meLi'an di rumah berhala dan patung karena tiada kehormatan padanya, dan keyakinan mereka padanya bukan syari'at.
Menurut Qadi Abu Ya’la dari ulama Hanabilah dan dari Ulama Hanafiyah tidak perlu menguatkan Li'an dengan tempat dan waktu tertentu, karen Allah swt telah memerintahkannya dan tidak mengaitkan dengan waktu dan tempat, maka tidaklah boleh mengaitkannya tanpa ada dalil, dan karena Nabi saw (hanya) memerintahkan si lelaki menghadirkan isterinya dan tidak mengkhususkan pada waktu tertentu, jika ada maka pastilah ada riwayat.

\section{KEHARUSAN KETIKA ADA SUAMI/ISTERI MENOLAK MENGUCAPKAN SUMPAH LI'AN ATAU MENGURUNGKANNYA.}

Kadang-kadang ada salah satu dari suami isteri menolak untuk mengucapkan Li'an setelah menuntutnya di muka hakim, dan terkadang ada yang membatalkan dan mengakui dirinya berdusta, apa tindakan hakim?

Adapun dalam keadaan salah satunya menolak bersumpah Li'an setelah ia menuntutnya, fuqaha berbeda pendapat dalam dua pandangan:

a. Ulama Hanafiah berpendapat, jika suami enggan bersumpah ia disandra sampai bersedia mengucapkan sumpah atau mengakui dirinya berdusta, maka ia dihad qazaf, dan bila si isteri yang menolak bersumpah ia pula yang disandra sampai mau mengucapkan sumpah Li'an atau ia membenarkan tuduhan suaminya, jika ia membenarkan tuduhan suaminya maka kosonglah jalannya dari tiada had, karena firman Allah swt. ويدرؤ yaitu penahanan menurut mereka dan menurut ulama Hanabilah.

b. Dan Jumhur ulama selain Hanafiah berpendapat bahwa jika suami enggan mengucapkan Li'an atau isteri yang enggan maka di had zina, karena sumpah Li'an adalah sebagai pengganti ويدرؤ عنها 
yaitu siksa dunia berupa had zina bagi mereka si isteri tidak bisa terhindar dari had kecuali ia mengucapkan sumpah Li'annya. Kecuali ulama Hanabilah menyetujui ulama Hanafiah apabila isteri menolak bersumpah adalah pengambilan madlul ayat itu, jadi jika dia tidak mengucapkan sumpah Li'an maka ia tidak bisa menghindari azab/hukuman, maka ia disandra sampai ia mengaku berzina sebanyak empat kali atau ia mengucapkan sumpah. Dan pendapat Jumhur yang lebih kuat karena kuatnya dalil mereka berdasarkan qur'an dan sunnah. Bahwa apabila seorang suami menuduh isterinya yang Muhsonah (suci) maka wajib ia di had qazaf dan dia dihukum fasiq dan kesaksiannya ditolak kecuali ia bisa mendatangkan bukti atau dengan melakukan Li'an, jika ia tidak dapat mendatangkan empat orang saksi atau menolak untuk melakukan Li'an maka wajiblah ia dihukum dengan semua itu. ${ }^{19}$

Dan terkadang suami wajib di atas penolakannya bersumpah Li'an berupa Ta'zir saja, seperti dalam hal qazaf terhadap wanita ghair muhsanah, seperti wanita ahl al-Kitab, budak sahaya, wanita gila, kanak-kanak, maka ia wajib mendapat hukum ta'zir, terkait terbebasnya ia dari qazaf, tidak juga wanita-wanita itu dihad dengan had sepenuhnya karena kekurangan mereka sebagaimana disebutkan, dan juga tidak dikaitkan dengan sifat fasiq tidak juga ditolak kesaksiannya, karena qazaf bagi mereka itu tidak wajib had, dan ia berhak mengucapkan Li'an untuk menolak hukum ta'zir karena itu adalah ta'zir dalam hukum qazaf.

Maka berlakulah kaidah, setiap tempat (keadaan) yang tidak berlaku Li'an padanya, maka nasab dihubungkan h. $576-7$ dengan suami, maka wajiblah dengan qazaf sebagai keniscayaannya dari had dan ta'zir, kecuali pelaku qazaf anak kecil atau gila, maka tidak ada ta'zir atau pun hukum dera baginya dan tidak juga hukum Li'an padanya.

\section{PEMBATALAN SUAMI ATAS SUMPAH LI'AN YANG IA UCAPKAN.}

Apabila suami mengaku dusta atas Li'an yang telah dia ucapkan, Imam empat mazhab sepakat bahwa ia dihukum had qazaf, dan bagi isteri ia berhak menuntut hakim melakukan had, sama apakah ia mendustakan diri sendiri sebelum ucapan Li'annya atau pun setelahnya, karena pernyataan Li'an berlaku sebagai alat bukti bagi suami, jika ia mendustakan diri sendiri dengan berkata: aku telah berdusta atasnya (istrinya), maka bertambah kehormatan isterinya dan berulang qazafnya, maka tidaklah kurang dari kewajiban atasnya had yang wajib dalam qazaf semata.

Jika ia kembali mengurungkan diri dari mengaku dusta, dan ia berkata, aku punya bukti yang bisa ku tegakkan bahwa ia telah berzina, atau ia ingin menggugurkan had darinya dengan mengucapkan Li'an, maka ia tidak boleh lagi didengar, karena bukti dan Li'an untuk meyakinkan apa yang ia katakan, padahal ia sudah mengakui kebohongannya, maka tidak lah boleh didengar darinya yang menyalahi pengakuan itu. Dan ini semua adalah dalam hal yang dituduh zina adalah wanita muhsan (Muslimah yang dilindungi), jika wanita bukan muhsan maka ia dihukum ta'zir.

Jika pelaku Li'an mengaku dirinya dusta sebelum meLi'an isterinya, ia di had qazaf, dan tetaplah (status) perkawinannya, dan wanita itu tetap isterinya, tetapi jika pengakuan setelah Li'an perkawinannya tidak lagi berlaku.

Dan apabila penafi anak mengaku dusta setelah ia menafi dan setelah Li'an 
maka nasab anak dihubungkan dengannya apakah anak itu hidup atau pun mati, anak itu kaya atau pun miskin, karena Li'an adalah sumpah atau kesaksian (bukti), jika ia mengaku dengan apa yang tadinya ia selisihi maka yang diambil adalah pengakuannya, dan gugurlah hukum Li'an, kemudian karena nasab meliputi ketetapan itu sesuai kemungkinan, dan sempurna hukum waris antara bapak dan anak karena kewarisan mengikuti nasab yang sudah ditetapkan sehingga kewarisan mengikuti. ${ }^{20}$

\section{APAKAH LI'AN ITU KESAKSIAN ATAU SUMPAH?}

Dalam pembahasan tentan syarat dua orang pelaku Li'an, menurut ulama Hanafiah, Hanyasanya yang boleh melakukan Li'an adalah orang yang boleh bersaksi, tidak boleh meLi'an kecuali antara dua orang muslim yang merdeka dan adil, syarat peLi'an adalah merdeka, berakal, baligh, Islam, bisa bicara dan tidak pernah dihukum had qazaf. Menurut Jumhur ulama, sah Li'an dari setiap suami isteri yang mukallaf, sama apakah muslim atau kafir, adil atau pun fasiq, atau keduanya pun pernah dihukum had atau salah satunya.

Dasar perbedaannya adalah dalam memandang apakah Li'an itu kesaksian atau sumpah, pendapat ulama Hanafiah Li'an itu adalah kesaksian yang dikuatkan dengan sumpah yang dikaitkan dengan laknat dan murka Allah, dan dari sisi suami dalam menegakkan had qazaf dandari sisi isteri dari soal had zina, dalil mereka adalah ayat Li'an. Dalam ayat ini شهداء suami isteri dinamakan para saksi dan di dalam Nash Li'an dinamakan kesaksian, dan bilangannya dijadikan seperti bilangan saksi dalam zina. Dan bilamana Li'an itu adalah kesaksian maka 576-8. disyaratkan juga padanya sebagaimana persyaratan kesaksian atas muslim. ${ }^{21}$

Pendapat Jumhur: lafaz Li'an itu disebut kesaksian, tetapi pada hakikatnya itu sumpah, meskipun ia disebut kesaksian, karena sabda Nabi dalam kisah Li'annya Hilal ibn Umayyah. Dan juga karena dalam Li'an harus menyebutkan nama Allah swt dan menyebut jawab qasam, kalau lah itu kesaksian maka tidak diperlukan, dan juga karena ia sama baik suami mau pun isteri kalau itu kesaksian mestilah isteri Cuma separuh Li'an saja, juga karena wajib mengulanginya sampai empat kali sementara dalam kesaksian tidak ada pengulangan dan juga karena Li'an terjadi dari dua pihak sementara kesaksian hanya dari satu pihak yaitu penggugat.

Adapun penyebutan $L i$ an sebagai kesaksian dalam nas itu karena redaksi ucapan dalam Li'an ada menyebutkan demi Allah aku bersaksi, sehingga Li'an juga disebut kesaksian meskipun ia adalah sumpah, dan kadang syahadat juga diibaratkan sumpah, seperti dalam firman Allah swt قالوا نشهد اذا جاءك المنافقون kemudian berkata اتخذوا ايمانهم خنة النة dan mereka berijma' bahwa Li'an dari orang buta boleh kalau lah itu kesaksian maka tiada dibolehkan Li'annya orang buta.

Maka jika Li'an itu sumpah, maka tidak lah disyaratkan padanya syaratsyarat kesaksian, maka berbedalah pendapat mereka pada orang bisu, jumhur berpendapat orang bisu dapat meLi'an jika bisa dipahami, menurut Hanafiah tidak bisa meLi'an karena orang bisu tidak boleh bersaksi.

Dan yang lebih kuat adalah pendapat jumhur karena kuatnya dalil mereka, karena Li'an itu disyari'atkan karena adanya hajat, dan hajat itu meluas h. 578 .
${ }^{21}$ Wahbah al-Zuhaili, al-Fiqh al-Islami....,

Perada: Jurnal Studi Islam Kawasan Melayu, Vol. 2, No. 2, Desember 2019 
kepada seluruh manusia meskipun mereka tidak boleh bersaksi. ${ }^{22}$

\section{AKIBAT LI'AN}

Berikut beberapa akibat Li'an yang diucapkan di hadapan hakim:

1. Gugurnya had qazaf atau hukum ta'zir dari suami dan gugurnya had zina atas istrei, jika suami tidak mengucapkan Li'an wajib atasnya had qazaf menurut ulama selain Hanafiah jika isteri yang diLi'an itu suci dan hukum ta'zir jika wanita yang dituduh bukan muhsan. Jika isteri tidak mengucapkan sumpah Li'an ia wajib dihad zina menurut ulama Malikiyahd an Syafi'iyah yaitu hukum cambuk (jilid) bagi yang perawan dan rajam bagi yang sudah menikah.

2. Haramnya bersetubuh dan berjimak setelah mengucapkan li;an dari kedua suami isteri meskpun sebelum diceraikan oleh hakim karena adanya hadis: dua orang yang mengucapkan Li'an tidak lagi bisa berkumpul selamanya.

3. Wajib menceraikan keduanya, menurut ulama Hanafiah tidak sempurna memisahkan keduanya kecuali dengan keputusan Hakim, dasarnya perkataan Ibn Abbas dalam kisah Hilal Ibn Umayyah: maka Nabi menceraikan keduanya, maka ini indikasi bahwa perceraian belum terjadi sebelum itu, jika salah satunya mati sebelum bercerai maka mereka saling mewarisi dan jika suami mengucapkan talak maka terjadilah talak itu.

Menurut ulama Malikiyah dan Hanabilah, yang lebih kuat berdasarkan riwayat Ahmad: Perceraian terjadi dengan Li'an bukan dengan putusan hakim, karena sebab perceraian yaitu lian sudah terjadi, maka terjadilah perceraian tanpa perlu putusan cerai dari hakim, dan juga

22 Wahbah al-Zuhaili, al-Figh al-Islami...., h. $579-80$. karena perkataan Umar r.a, Dua orang yang mengucapkan Li'an diceraikan keduanya dan tidak lagi boleh berkumpul selamanya.

Menurut Imam Syafi'i, telah berakibat cerai dengan sumpah Li'an suami saja meskipun isteri tidak mengucapkan Li'an, karena perceraian terjadi sebagai akibat dari ucapan, maka terjadilah dengan ucapan suami sendiri seperti ucapan talak, menurut Ibn Qudamah dalam kitab al-Mughni: kami tidak tahu seorang pun yang setuju dengan pendapat Syafi'i ini.

4. Menurut Abu Hanifah perceraian ini termasuk talak ba'in dan Muhammad, karena dengan putusan hakim sama seperti perceraian disebabkan impoten, setiap perceraian dengan putusan hakim termasuk talak ba'in, tetapi si perempuan tidak akan boleh kembali dikawini kecuali dalam dua keadaan:

a. Si suami menyatakan ia telah berdusta meskipun ada dalil seperti anak yang dinafi meninggal suai mengakui nasabnya karena ini dianggap ia membatalkan kesaksiannya, dan kesaksian tiada hukumnya jika ia membatalkannya, dan ia di had dengan had qazaf, dan ditetapkanlah nasab anak dan begitu juga kembali lah si isteri dalam perkawinan jika perempuan membenarkannya.

b. Salah satu dari suami isteri keluar dari kebolehan menjadi saksi; karena dengan itu menafi sebab perceraian, maka walau perempuan itu berzina atau ia menuduh selainnya maka terjadilah, maka bolehlah suaminya menikahinya karena ternafikannya kebolehan meLi'an dari sisi isteri.

Dan apabila itu talak ba'in, maka wajib bagi isteri berupa nafkah dan tempat tinggal dalam masa iddahnya dan ditetapkan nasab anaknya. 
Berkata Jumhur dan AbuYusuf, perceraian dalam Li'an adalah fasakh (pembatalan) sama seperti percerian dalam menyusui, dan wajib keharaman selamanya, kedua suami isteri tidak boleh kembali kawin setelah itu untuk selamanya, karena Li'an bukanlah talak, maka itu adalah fasakh sama seperti semua yang difasakh suami, dan karena Li'an itu adalah kewajiban dan dia menjadi sebab perceraian adapun bila suami mengaku ia telah berdusta atau keluarnya salah satu dari peLi'an dari kebolehan menjadi saksi maka itu tidaklah menafi terjadinya sebab perceraian bahkan ia telah tetap dan berkekalan hukumnya.

Dan pendapat Imam Syafi'i, Percerian terjadi dengan Li'annya suami meskipun isteri tidak mengucapkan Li'an, jika ia berdusta atau mengaku berdusta, maka itu tidaklah berfaedah mengembalikan pernikahannya dan tidak juga mengangkat hukum keharamannya karena keduanya itu hak baginya yang keduanya itu telah ia batalkan dengan Li'annya, maka tidaklah memungkinkan untuk kembali, berbeda dengan had dan hubungan nasab maka berdusta dan mengaku dusta mengembalikan kedudukannya karena itu haknya.

5. Hilangnya Nasab anak dari si bapak, dan menghubungkan nasab dengan ibunya jika Li'an itu tujuannya menafi anak, sehingga tidak punya hubungan waris dan tidak ada kewajiban nafkah., baik nafkah bapak kepada anak maupun nafkah anak kepada bapak.

Ini juga menimbulkan keadaankeadaan hukum bagi anak antara lain; tiada kebolehan kesaksian anak kepada asal Pelaku Li'an dan asal kepada cabangnya, tiadanya hak meminta hukum qisas kepada pembunuh anak yang dinafi, tidak sahnya menghubungkan nasab anak dengan orang lain karena pengakuan dusta peLi'an sehingga nasab kembali kepadanya, tetapnya hukum mahram, maka si lelaki penafi tidak boleh menikahi anak perempuan dari anak yang dinafi karena mengandung konsekwensi itu adalah anaknya. ${ }^{23}$

\section{HAL-HAL YANG MENGGGUGUR- KAN KEWAJIBAN LI'AN}

Ulama Hanafiah menetapkan bahwa kewajiban Li'an gugur dengan halhal berikut:

1. Masalah tiadanya kecakapan atau kemampuan meLi'an atau apa yang asalnya menghalang kemestian mengucapkan Li'an: setiap yang menghalangi kewajiban mengucapkan Li'an, bila keadaan itu muncul kewajiban itu gugur, seperti jadi gila atau murtad atau bisu atau ia telah mengqazaf (menuduhzina) orang lain dan ia dihad qazaf, atau ia pernah menyetubuhi perempuan lain secara haram seperti ia pernah berzina atau menyetubuhi wanita secara syubhat, maka dalam keadaan-keadaan ini tidak wajib had, jika diwajibkan maka itu gugur dengan alasan-alasan ini karena hilangnya kecakapan meLi'an. Karena Li'an itu adalah persaksian sehingga harus ada sifat dan syarat-syarat bersaksi untuk menimbulkan hukum.

2. Adanya kejelasan hukum dengan talak (ba'in) atau fasakh atau adanya kematian, jika suami mentalak isterinya setelah ia menuduh zina atau suami memfasakh isterinya atau meninggal salah satu dari suami isteri maka gugurlah Li'an dan hukum had, adapun gugurnya Li'an karena telah hilangnya perkawinan. Masih tegaknya status perkawinan merupakan syarat kebolehan Li'an sebagaimana telah dijelaskan, adapun ketiadaan hukum had, karena qaraf mewajibkan Li'an h. $581-2$. 
bukan mewajibkan had. Adapaun jika suami mentalak isterinya dengan talak raj'i, maka itu tidak menggugurkan Li'an karena talak raj'i tidak membatalkan status perkawinan.

3. Kematian Pelaku Qazaf atau hilang, Lian gugur dengan matinya saksi Qazaf atau hilang, karena kalau ia mati atau hilang tidak bisa diputus dengan kesaksiannya.

4. Suami mengaku dusta atau suami membenarkan isterinya dalam qazaf: jika suami mengaku dusta dalam qazafnya maka gugur Li'an, karena lemah untuk mewujudkannya, maka wajib atasnya had qazaf karena qazafnya sah.

Jika isteri membenarkan tuduhan suaminya gugurlah Li'an juga karena sudah lemah untuk mewujudkannya, karena si isteri sudah mengakui pengingkarannya itu dusta, tetapi tidak ada hukum had atas dirinya, karena Li'an kalaupun ia diharuskan tidaklah menetapkan adanya zina atas diri isteri, tidak juga menghilangkan kehormatannya dengan adanya Li'an, maka ia tidak di had dengan had zina, dan itulah yang lebih utama karena gugurnya Li'an. ${ }^{24}$

Ulama Hanabilah menyebutkan tiga

hal yang menggugurkan Li'an:

1. Munculnya kelemahan dari beberapa kecakapan, seperti gila, berzina dan isteri yang bisu

2. Isteri membenarkan tuduhan suaminya atau memaafkannya atau mendiamkannya, dan dua sebab hal ini adalah syarat mereka, bahwa ia mendustakannya dan terus berdusta sampai dilakukannya Li'an.

3. Meninggalnya suami sebelum Li'an atau sebelum sempurna mengucapkan Li'an, maka disepakati gugurlah Li'an, dan nasab anak dihubungkan dengannya dan isteri mewarisinya, h. 582 .

24 Wahbah al-Zuhaili, al-Figh al-Islami...., karena Li'an belum terjadi sehingga akibat hukum tidak terjadi, demikian juga Li'an gugur jika ia meninggal dalam keadaan lian suami sudah selesai sementara Li'an isteri belum dilakukan.

Menurut Imam Syafi'i, isteri tertalak bain dengan liannya suami, meskipun isteri belum mengucapkan Li'an, atau jika ternyata suami berbohong, dan gugur hak saling mewarisi dan anak dinafi, dan isteri mesti di hukum had kecuali ia bersedia mengucapkan Li'an.

\section{YANG MEMBATALNYA HUKUM LI'AN SETELAH ADANYA SEBELUM PERCERAIAN}

Pendapat ulama Hanafiah: Bahwa setiap yang menggugurkan Li'an setelah kewajibannya, maka ia membatalkan hukum Li'an, yaitu akibat hukumnya, setelah terwujudnya, Sebelum perceraian seperti gilanya salah satu dari suami isteri atau keduanya setelah Li'an sebelum perceraian, atau suami bisu atau pun keduanya bisu, atau suami murtad atau keduanya murtad atau salah satunya pernah dihad qazaf atau si isteri pernah melakukan hubungan badan secara haram, dan mengaku dusta salah satunya sehingga hakim tidak menceraikan keduanya dan keduanya tetap dalam perkawinan mereka.

Dan itu karena hukum asalnya bagi keduanya adalah tetapnya antara kedua suami isteri itu atas keadaan Li'an dari segi kecakapan merupakan syarat tetap adanya hukum Li'an, karena Li'an mereka itu adalah kesaksian, sehingga syaratsyarat saksi harus tetap ada pada mereka sampai timbulnya putusan peradilan. Jika hilang sifat (prasyarat) kesaksian dengan sebab-sebab itu maka hakim tidak boleh memutuskan cerai. ${ }^{25}$

25 Wahbah al-Zuhaili, al-Figh al-Islami...., h. $581-2$. 


\section{SUMPAH LI'AN DAN TATACARA PENERAPANNYA DI PENGADIL- AN AGAMA}

Berdasarkan penelusuran peraturan perundang-undangan yang berlaku di lingkungan Peradilan Agama sejauh yang telah peneliti lakukan, aturan tentang Hukum Li'an dan tatacaranya hanya terdapat di dalam Instruksi Presiden Nomor 1 Tahun 1991 tentang Sosialisasi Kompilasi Hukum Islam. Pada undangundang dan peraturan sebelumnya, yakni Undang-undang Nomor 1 Tahun 1974 tentang Perkawinan dan Penjelasannya tidak ada mengatur tentang Li'an sebagai penyebab putusnya perkawinan, demikian juga di dalam Peraturan Pemerintah Nomor 9 Tahun 1975 tentang Aturan Pelaksanaan Undang-undang Perkawinan juga tidak ditemukan aturan tentang Li'an.

Ketentuan dan aturan tentang Sumpah Li'an terdapat di dalam Pasal 125 s/d 128 Kompilasi Hukum Islam, Inpres No. 1 Tahun 1991 (Selanjutnya disebut KHI). Pasal tentang Li'an ini di dalam KHI diletakkan di Bab XVI, Tentang Putusnya Perkawinan, Bagian Kesatu, Umum.

Pasal 25 KHI menyatakan bahwa Sumpah Li'an menyebabkan putusnya perkawinan antara suami isteri untuk selama-lamanya. Bahwa Li'an terjadi karena suami menuduh istri berbuat zina dan atau untuk mengingkari anak dalam kandungan atau yang sudah lahir dari istrinya, sedangkan istri menolak tuduhan dan atau pengingkaran tersebut. ${ }^{26}$ Bahwa Li'an hanya sah apabila dilakukan dihadapan sidang Pengadilan Agama. ${ }^{27}$

Selanjutnya tatacara li'an diatur sebagai berikut. Pertama; Suami yang menuduh istrinya telah berbuat zina atau hendak mengingkari anak dalam kandungan atau yang lahir dari istrinya bersumpah sebanyak 4 (empat) kali

\footnotetext{
${ }^{26}$ Pasal 126 KHI

27 Pasal 128 KHI
}

dengan kata tuduhan zina dan atau pengingkaran anak dan kemudian diikuti dengan ucapan sumpah yang kelima dengan kata-kata "Laknat Allah atas dirinya apabila tuduhan dan atau pengingkaran tersebut dusta. ${ }^{28}$

Kedua; Istri menolak tuduhan dan atau pengingkaran tersebut dengan juga mengucapkan sumpah sebanyak empat kali yang menyatakan bahwa "tuduhan dan atau pengingkaran suaminya tersebut tidak benar", selanjutnya diikuti sumpah kelima dengan kata-kata murka Allah atas dirinya bila "tuduhan dan atau pengingkaran anak oleh suaminya tersebut benar. $^{29}$

Pasal 127 huruf $c$ dan d menyatakan bahwa tata cara Li'an yang diatur pada bagian sumpah suami dan sumpah isteri ini merupakan satu kesatuan yang tak terpisahkan, dan apabila tata cara pada Huruf a tidak diikuti dengan tata cara huruf b, maka dianggap tidak terjadi li'an.

Selanjutnya peneliti juga melakukan penelusuran soal bagaimana penerapan aturan tentang Li'an ini di Pengadilan Agama. Dalam hal ini peneliti melakukan wawancara kepada beberapa orang responden yang berasal dari unsur hakim dan kepaniteraan di Pengadilan Agama Tanjungpinang dan Pengadilan Agama Bengkalis.

Berdasarkan hasil dialog dan wawancara yang peneliti lakukan, didapatkan informasi berupa keadaan faktual pelaksanaan pemeriksaan perkara perceraian di Pengadilan Agama, khususnya perkara perceraian dengan alasan tuduhan zina dan perselingkuhan. Bahwa, menurut Hakim YM Drs. Daswir, MH., ${ }^{30}$ berdasarkan pengalaman puluhan

\footnotetext{
28 Pasal 127 Huruf a

${ }^{29}$ Pasal 127 Huruf b

30 Beliau adalah Hakim Senior di Pengadilan Agama Tanjungpinang, wawancara pada Oktober 2018 di Pengadilan Agama Tanjungpinang.
} 
tahun memeriksa perkara perceraian, belum pernah satu pun beliau temukan perkara Li'an atau pun mendengar rekan hakim lainnya yang ada memeriksa perkara li'an. Meskipun beliau mengakui ada banyak perkara perceraian yang diperiksa alasannya mengarah pada tuduhan zina baik dari suami maupun dari isteri, akan tetapi perkara ini lebih lazim disebut dengan alasan perselingkuhan. Jadi penyebab perceraiannya adalah perselingkuhan. Beliau mensinyalir bahwa ketentuan Kompilasi Hukum Islam tentang Li'an tidak pernah digunakan dalam menyelesaikan sengketa perceraian, alasan-alasan perceraian lebih banyak mengacu kepada alasan perceraian dalam Undang-undang Perkawinan dan Peraturan Pemerintah Nomor 9 Tahun 1975 tentang Aturan Pelaksanaan Undang-undang Perkawinan berikut tambahan alasan perceraian sebagaimana disebut dalam pasal 116 KHI.

Adapun ketentuan Li'an dalam KHI menurut beliau memang begitulah ketentuannya bahwa antara sumpah suami dan sumpah bantahan dari istri itu merupakan satu kesatuan, dan itu sudah sesuai dengan ketentuan ayat Li'an dalam surat al-Nur. Bahwa Li'an dianggap tidak terjadi jika istri tidak mengucapkan sumpahnya.

Menurut Hakim dan sekaligus Ketua Pengadilan Agama Tanjungpinang, YM. M. Ali Syarifuddin, Lc, SH, M.Ag, ketika peneliti tanyakan soal hukum Li'an dan penerapannya di Pengadilan Agama, beliau menyatakan bahwa pelaksanaan Li'an di Pengadilan Agama itu berat untuk dilakukan, mengingat konsekwensi dan akibat hukumnya dalam hukum Islam, sehingga kebanyakan perceraian yang ada kaitan dengan tuduhan zina dan atau pengingkaran anak, diselesaikan dengan tatacara perceraian biasa. ${ }^{31}$

31 Wawancara dengan Bapak M. Ali Syarifuddin, Lc, SH, M.Ag, Ketua Pengadilan
Demikian juga pendapat Hakim YM. M. Zen, $\mathrm{MH}^{32}$ bahwa memang aturan dan tatacara Li'an sebagaimana yang tertuang di dalam KHI tidak fungsional, karena sejauh pengalaman beliau menjadi hakim, tidak pernah satu pun ada perkara yang diselesaikan dengan tatacara Li'an. Di samping akibat hukum yang dianggap berat, karena pengucapan sumpah ini terkait laknat dan murka Allah, juga mengakibatkan putusnya perkawinan untuk selamanya. Sehingga bukan hanya warga masyarakat yang tidak pernah mengajukannya tetapi juga sedapatnya dihindari dari penyelesaian dengan cara li'an ini. Sehingga kebanyakan perkara percerian dengan tuduhan perselingkuhan yang mengarah pada tuduhan zina, diselesaikan dengan cerai biasa, yaitu perceraian dengan alasan pertengkaran dan perselisihan. Kalau pun ada pengucapan sumpah, itu bukanlah sumpah li'an, tetapi sumpah untuk kegunaan pembuktian sebagaimana sumpah dalam hukum acara perdata biasa, dan tidak dikaitkan dengan laknat dan murka Allah swt.

Menurut YM. M. Zen, MH., memang perlu dikritisi juga redaksi pasal $27 \mathrm{KHI}$ itu, yang menganggap Li'an yang telah diucapkan suami dianggap tidak terjadi jika istri tidak bersedia mengucapkan sumpah bantahan. Karena jika begitu suami yang telah mengucapkan sumpah bisa saja rujuk atau kembali menikahi istri yang sudah ia ucapkan sumpah Li'an itu. Akan tetapi keadaan ini belum pernah terjadi karena memang penyelesaian dengan jalan Li'an itu sendiri belum pernah ada. Memang menurut beliau banyak ketentuan-ketentuan hukum di dalam KHI yang dirasakan belum ideal.

\footnotetext{
Agama Tanjungpinang, pada Oktober 2018 di STAIN Sultan Abdurrahman Kepulauan Riau.

32 Wawancara pada Oktober 2018 di STAIN Sultan Abdurrahman Kepulauan Riau.
} 
Demikian juga keterangan dan pendapat Panitera Pengadilan Agama Tanjungpinang yang menyatakan bahwa, selama beliau menjadi Panitera Sidang yang mengikuti proses pemeriksaan perkara perceraian, memang terdapat banyak perkara perceraian yang dilatarbelakangi oleh isu perselingkuhan dan perzinahan, tetapi belum ada satu pun pihak suami yang mengajukan dengan jalan Li'an, tetapi semua dengan alasan ketidak harmonisan rumah tangga, dengan kata lain tuduhan zina itu oleh masyarakat lebih dikenal dengan tuduhan perselingkuhan yang akibatnya menyebabkan ketidakrukunan rumah tangga sehingga menyebabkan perselihan dan pertengkaran rumah tangga. ${ }^{33}$

Selanjutnya peneliti juga berkesempatan melakukan wawancara dengan seorang Hakim Pengadilan Agama Bengkalis dan juga dengan seorang Panitera Muda di Pengadilan Agama Bengkalis. Menurut Hakim YM. Muhammad Kadafi Bashori, SHI., Memang selama ini perkara perceraian terdapat juga penyebab yang mengarah kepada tuduhan zina dan juga pernah ia dapatkan pernyataan pihak suami yang tidak mengakui anak yang dilahirkan isterinya. Tetapi semuanya diselesaikan dengan alasan pertengkaran dan perselisihan antara suami isteri, sehingga belum ada yang mengarah kepada pembuktian dengan sistem Li'an. ${ }^{34} \mathrm{YM}$. Kadafi juga mengutip pandangan seorang mantan Hakim Agung yang dahulu pernah menjabat Ketua Pengadilan Tinggi Agama Riau, Yaitu YM. Habiburrahman, bahwa menurut beliau KHI itu masih banyak perlu penyempurnaan sehingga dapat fungsional untuk dijadikan dasar dalam

\footnotetext{
${ }^{33}$ Wawancara dengan Panitera Pengadilan Agama Tanjungpinang di Pengadilan Agama Tanjungpinang pada Oktober 2018.

34 Wawancara di Pengadilan Agama Bengkalis, 19 November 2018.
}

memutus perkara, belum lagi adanya persoalan payung hukumnya yang bukan berupa Undang-undang dan hanya Instruksi Presiden yang dalam hirarkis peraturan perundang-undangan, Instruksi Presiden tidak termasuk ke dalam hirarkis Peraturan Perundang-undangan. ${ }^{35}$

Panitera Muda Pengadilan Agama Bengkalis, Helmi Cendra, S.Ag, MH. Juga menambahkan bahwa selama beliau mendampingi hakim dalam memeriksa perkara, memang tidak pernah mengarah kepada pengucapan sumpah Li'an, meskipun dari pernyataan pihak suami ada kalimat menuduh istri berbuat zina dengan orang lain atau bahkan pernyataan tidak mengakui anak yang dikandung dan dilahirkan oleh isterinya. Menurut beliau ini juga disebabkan keterbatasan pengetahuan agama masyarakat dan juga keawaman mereka soal hukum dan perundang-undangan. Ini tidak hanya dalam sidang-sidang di Pengadilan Agama Bengkalis, tetapi juga dalam sidang keliling di wilayah-wilayah yurisdiksi Pengadilan Agama Bengkalis. ${ }^{36}$

Demikianlah berbagai informasi dan pandangan dari kalangan Praktisi di Pengadilan Agama soal hukum acara Li'an yang terdapat di dalam Kompilasi Hukum Islam, dalam prakteknya ternyata memeng belum pernah terjadi dan fungsional di lingkungan Peradilan Agama.

\section{KESIMPULAN}

Berdasarkan penelusuran kepustakaan dan hasil penelusuran di lapangan maka sebagai hasil penelitian didapatlah beberapa kesimpulan penelitian ini. Pertama, mekanisme Li'an di Lingkungan Peradilan Agama, sebagaimana yang tercantum di dalam Pasal 127 Kompilasi Hukum Islam, mengacu kepada al-Qur'an Surat al-Nur ayat $6 \mathrm{~s} / \mathrm{d}$ ayat 9 . Kemestian

${ }_{35}^{35}$ Ibid.
$36 \quad$ Wawancara di Pengadilan Agama
Bengkalis, 19 November 2018.


terpenuhinya sumpah tidak hanya dari pihak suami sebagai penuduh zina, tetapi juga harus ada pengucapan sumpah dari pihak isteri yang menolak tuduhan tersebut untuk terjadinya cerai dengan jalan Li'an secara normatif adalah untuk memenuhi ketentuan ayat al-Qur'an tersebut.

Kedua, berdasarkan penelusuran kepustakaan dapat disimpulkan bahwa mayoritas ulama (jumhur) mensyaratkan Li'an terjadi jika tatacaranya sesuai dengan kronologis ayat al-Qur'an, sehingga Li'an berikut akibat hukumnya baru dianggap terjadi jika itu terpenuhi. Namun menurut Imam al-Syafi'i, meskipun Isteri tidak mengucapkan sumpah penolakan, jika suami telah selesai mengucapkan sumpahnya, yakni sampai sumpah yang ke-lima, maka akibat li'an berupa putus perkawinan untuk selamanya, sudah terjadi.

Berdasarkan hasil wawancara kepada sejumlah hakim di dua pengadilan yang dijadikan sample penelitian, didapati fakta bahwa sejak pasal 127 KHI dimunculkan tahun 1991, sampai saat ini faktanya belum pernah ada perkara perceraian yang berakhir dengan pengucapan sumpah li'an di Pengadilan Agama. Jika pun ada perkara perceraian dengan faktor tuduhan zina dan atau pengingkaran anak, semuanya ternyata tidak diarahkan kepada pembuktian dengan jalan li'an tetapi menjadi penyebab ketidak rukunan rumah tangga sehingga alasannya adalah perselisihan dan pertengkaran suami isteri yang tidak dapat didamaikan kembali.

Berdasarkan kesimpulan yang peneliti dapatkan, di sini peneliti merasa perlu memberikan beberapa rekomendasi dan saran-saran:

1. Kepada Pemerintah dan Legislator agar memberi perhatian terhadap legislasi hukum perkawinan Islam, tidak hanya aspek idealitas tetapi juga aspek fungsionalitas aturan itu sendiri sehingga benar-benar sesuai dengan kebutuhan hukum masyarakat Islam Indonesia.

2. Kepada Aparatur Peradilan diharapkan mengagendakan sosialisasi dan pemahaman hukum Islam di Indonesia secara lebih terprogram kepada masyarakat.

3. Perlu dirumuskan format pemberlakuan hukum Islam dari khazanah fiqh ke dalam paraturan perundang-undangan dengan juga memperhatikan relevansinya dengan kebutuhan masyarakat untuk keperluan dalam dataran praksisnya dan tidak hanya menekankan idealitas sehingga hukum yang berlaku benar-benar diaplikasikan dalam dunia peradilan.]

\section{DAFTAR PUSTAKA}

Al-Ghazali, Muhammad bin Muhammad, 1980, Ihya' Ulum al-Din, Beirut: Dar al-Fikr.

, Muhammad bin Muhammad, Ayyuha al Walad Fi Nashihati al Muta'allimin Wa Mau'izhatihim Liya'lamuu Wa Yumayyizuu 'Ilman Nafi'an, Jakarta: Al Haramain Jaya Indonesia

Al-Mansur, Anshori, 2000, Cara Mendekatkan Diri pada Allah, Jakarta: Grafindo Persada

Fuaduddin, 1999, Dinamika Pemikiran Islam di Perguruan Tinggi, Jakarta: Logos

Hasbullah, Dasar-Dasar Ilmu Pendidikan Islam, (Jakarta: Raja Grafindo Persada, 2009), hlm. 1

Ibnu Rusn, Abidin, 2009, Pemikiran AlGhazali tentang Pendidikan. Yogyakarta: Pustaka Pelajar. 
Juwariyah, 2010, Dasar-Dasar Pendidikan Anak dalam Al-Qur'an, Yogyakarta: Teras
Zainuddin, 1991, Seluk Beluk Pendidikan dari Al Ghazali, Jakarta: Bumi Aksara.

Muhammad, 2003, Pendidikan di Alaf Baru Rekrontruksi atas Moralitas Pendidikan, Yogyakarta: Primashopie.

Muslich, Mansur, 2011, Pendidikan Karakter Menjawab Tantangan Kritis Multidimensial, Jakarta: Bumi Aksara.

Mustofa, A. 2007, Filsafat Islam, Bandung: Pustaka Setia

Poerwodarminta, WJS, Kamus Umum Bahasa Indonesia, Jakarta: Balai Pustaka, 1999).

Syah, Muhibbin, 2003, Psikologi Belajar, Jakarta: Raja Grafindo.

Syahidin, Aplikasi Metode Pendidikan Qur'ani dalam Pembelajaran Agama di Sekolah, (Tasikmalaya : IAILM Pondok Pesantren Suryalaya, 2005).

Tafsir, Ahmad Ilmu Pendidikan dalam Perspektif Islam, (Bandung : Rosdakarya, 2007), cet. ke-7 , 1995 Metodologi Pengajaran Agama Islam, Bandung: Remaja Rosdakarya.

2006, Filsafat Pendidikan Islami; Integrasi Jasmani, Rohani dan Kalbu, Memanusiakan Manusia, Bandung: Remaja Rosdakarya.

Thabanah, Badawi, tt. Ihya Ulumuddin li al-Imam al-Ghazali ma'a muqaddimah fi tasawuf al-Islami wa dirasati tahliliyati li syakhshiyati al-Ghazali wa falsafatihi fi al-Ihya, Darul Ihya al'Arabiyah Indonesia. 